May - 2021

\title{
IDEAS for Transforming Higher Education: An Overview of Ongoing Trends and Challenges
}

Lourdes Guàrdia1, Derek Clougher ${ }^{1}$, Terry Anderson'2, and Marcelo Maina1

1 Universitat Oberta de Catalunya, ${ }^{2}$ Athabasca University

\begin{abstract}
The recent unexpected impact of the global pandemic on higher education has caused universities, governments, students, and teachers to reexamine all components of existing systems, including how to become more effective and efficient in using technologies for education. We have seen that moving classes online-either blended or fully online-can be done rapidly, but early reports show huge variations in quality, acceptance, completion, and learning. Thus, it is important to examine the existing research literature on pedagogical innovations and practices that use technologies. To understand this complex situation, the present study examines the current technological, organisational, and pedagogical trends and challenges using an exploratory design carried out in three stages. In stage one, a literature review of the academic and grey literature was conducted, identifying 14 trends of interest. These trends were used in a workshop and interview discussion between leading experts in the higher education field. Stage two focused on identifying 108 initiatives that represent these trends. Finally, 30 of these were selected as cases for further exploration in stage three. Using thematic analysis, the 30 cases were condensed into 12 main themes that represent the innovative practices that led to development of the IDEAS framework as a signpost on the roadmap of next-generation pedagogy for transforming higher education. IDEAS is presented in the discussion alongside examples and ways to apply it in higher education contexts.
\end{abstract}

Keywords: higher education, educational technology, trends and challenges in higher education, higher education transformation, next-generation pedagogy, strategic and organisational planning 


\section{Introduction}

In a progressively networked society, educators are faced with countless possibilities for strategic and opportunistic expansion (Henderikx \& Jansen, 2018). While benefiting our society with increased access to education (Baldwin \& Ching, 2019) and innovative teaching methods (Walder, 2017), this highly interconnected world also presents many challenges, given the societal expectations put on institutions (Posselt et al., 2018). The government, students, and society expect universities to be innovative, affordable, and cost-effective to remain relevant and provide quality education (Damewood, 2016), highlighting an ongoing transformation that signals an "increased convergence of many concerns: pedagogy, professional training, [and] the transfer of knowledge" in higher education institutions (Ruano-Borbalan, 2019, p. 493). Managing the transformation presents challenges for educators and education administrators as new pedagogies and technologies continue to materialize, driving the need for effective strategic planning and decision-making processes that guide their implementation (Bennett et al., 2018).

Advances in technology drive the emergence of innovative pedagogies and practice that in turn generate a "digital disruption of education" (De Wit et al., 2015, p. 77), acting as a catalyst for the main developments in higher education (Haywood et al., 2015). These effects are found at institutions delivering distance and online education and traditional face-to-face-only universities that move towards greater use of technology and interactive methodologies, providing a combination of classroom experience with the convenience and flexibility of online provision, increasing student interaction and engagement (Phoong et al., 2019). Thus, technology supports traditional models of higher education as a transformative complementary tool (Goh et al., 2020).

However, what are the most effective pedagogical innovations implemented in digital learning environments? To respond, it is necessary to understand the core trends and challenges in higher education that could transform decision making about the future of education (DeVries, 2019) and identify practices that can be adopted in urgent and unprecedented situations, such as the COVID-19 pandemic, allowing universities to continue providing high-quality education (Bates, 2020). The COVID-19 pandemic highlights that disruptive pedagogical practices are implemented to respond immediately (Rapanta et al., 2020), but reports from early studies provide a mixed review of the effectiveness of emergency remote education (Bozkurt et al., 2020), which differs from the usual practices of distance and online education that benefit from extensive a priori strategic planning and organisation, thus impacting the quality of course design, development, and delivery (O'Keefe et al., 2020). Additionally, many teachers have little or no experience teaching in an online environment, and the rapid transition revealed a lack of expertise as an area in great need of further support going forward in the new normality (Johnson et al., 2020).

\section{Trends in Higher Education}

Trends provide a unique insight into the approaches that universities are taking to differentiate themselves in the fast-evolving educational environment, giving an overview of the state of the art of higher education (Westine et al., 2019). We operationalize trends as broad predominant directions in which higher education is developing and transforming. 
Various reports identified in our study detail the current trends in higher education related to technology-enhanced teaching and learning, such as "The Changing Pedagogical Landscapes Study" (Henderikx \& Jansen, 2018), which cites technology as a means to "solve problems higher education is facing today and ... offer new opportunities for teaching and learning" (p. 3). The main trends reported include leadership and institutional strategy, gradual innovation at the course and curriculum levels, incentives for digital education, increased (scalable) continuous education and continuous professional development offerings, massive open online courses (MOOCs) as enablers for innovation, increasing internationalization of higher education, and the important role of governments. Moreover, institutions' capacity and resistance to implement technology were investigated, revealing that a lack of digital and media competences, absence of necessary institutional policies, and infrastructural limitations were the principal difficulties facing pedagogical innovation. The report suggests that blended learning methods are a trend driven by students' and teachers' digital skills, coupled with increased capability and reduced costs of the technology itself. Furthermore, the use of blended methods is recommended to complement, rather than replace, existing methods, as they improve quality while reaching a larger, more diverse population. Therefore, institutional policies and trends must adjust to the demand and be student-focused rather than teacher-focused forms of active learning.

Similarly, the Internationalization in Higher Education for Society publication (Brandenburg et al., 2020) addresses the crucial role that digital learning plays as a catalyst for the internationalization and mobility of both instructors and students. Its study references collaborative online international learning via technology-enabled virtual mobility as a key trend. Technological transformation is a vital factor in bridging the gap between universities and society, making the institutions more accessible to the wider public, including vulnerable communities, and it can extend education within the local society and beyond to national and international levels. Internationalization in higher education should focus on economic developmental models as well as taking into account factors such as economic growth, technology transfer and innovation (Brandenburg et al., 2020), reinforcing the importance of internationalization of digital learning, which in itself is considered a strategic issue in higher education development (De Wit et al., 2015).

The 2020 EDUCAUSE Horizon Report (Brown et al., 2020) focuses on five categories of trends: social, technological, economic, higher education, and political. Technological trends include advancements in artificial intelligence (AI), next-generation digital learning, and analytics and privacy questions. The authors discuss the economic impact of the trends, stating that institutions "will need to adjust their courses, curricula, and degree programmes to meet learners' needs as well as the demands of new industries and an evolving workforce" (p. 10). Technological advances respond to students' needs as they increasingly seek nontraditional routes to education, underlining that "higher education institutions are moving to new models for online programmes, such as assessment (competency) and crediting (micro-credentials and digital badging)" methods (p. 11).

Finally, it is necessary to reiterate that the COVID-19 pandemic has revealed a new major trend in that it has increased higher education's dependency on the use of technology for teaching and learning as emergency online courses have been implemented without the necessary time frame to prepare for this move (Hodges et al., 2020). Nonetheless, merely moving traditional-style classrooms online is not enough to deliver a consistent quality of education (Gasevic, 2020). The aforementioned trend reports argue that technology provides a viable solution to designing and supporting more flexible educational models, which are adaptable to educational, social, and economic needs as they arise. As such, the current debate on the future of the university system questions the foundations of the institution as it is compelled to 
adapt to a social context where technology plays a predominant role. This does not mean that existing teaching models should be replaced but rather that universities use technological advances to enhance traditional forms of pedagogy expanding the pedagogical possibilities thanks to the affordances of technology (Wick \& Lumpe, 2015).

\section{Challenges}

Despite the advantages associated with pedagogical innovations supported by technology, challenges exist. Technology has been implemented slower than expected (Marshall, 2018). Although universities strive to remain innovative, the use of technologies, societal digitalization, and societal and economic limitations highlight the difficulties they face (Posselt et al., 2018). These impact teachers, learners, and decision making in terms of structural and content design (Ponomarenko et al., 2019).

Barriers to technology implementation include how the role of the teacher changes once it is introduced (Bates, 2019). Understanding this role may explain the differences in technology use between novice and experienced teachers. In a 10-year longitudinal study, novice teachers in Sweden were more likely than their experienced counterparts to implement new technologies in their educational practices (Englund et al., 2017). Similarly, teachers' attitudes towards and beliefs about technology implementation were the strongest influences in its implementation at Dutch universities (Farjon et al., 2019). This represents an ongoing challenge as it is vital that all members of the institution adopt a prochange attitude to drive innovative pedagogical practices at the level of strategy and organisational planning (Bates, 2019). However, these attitudes are not always easily adopted: $93 \%$ of interviewed teachers in Australian universities have identified teacher resistance to technology implementation as a core barrier (Watty et al., 2016).

Moreover, choosing the most appropriate tools and learning activities for teachers' and learners' needs is a time-consuming process (Bates, 2019). The rapid pace at which technological innovations are introduced often eclipse teachers' capacity to gain successful competence prior to use (Sutton \& DeSantis, 2017). Academic staff must acquire an advanced level of digital and technological competency (Gillett-Swan, 2017). Therefore, collaborative learning via e-learning platforms and social networks, as well as online virtual collaboration between teachers, is needed (Romero-Moreno, 2019). Nevertheless, teachers differ in their opinions as to how technology can and should be used. Jääskelä et al. (2017) identify the following teachers' belief groups about digital learning: "[It is] a pivotal tool for self-paced learning, an additional tool for active and interactive learning, a tool designed for the integration and assessment of learning, and a tool for changing the learning culture" (p. 202). Moreover, a growing need for teachers' digital competence (DC) in higher education requires ongoing support in digital teaching methods (Amhag et al., 2019).

Further challenges upon implementation of the technology are seen in credentialization as the use of digital badge programmes includes usability issues, increased faculty workload, and a lack of information about their introduction (Stefaniak \& Carey, 2019). Both learning analytics and AI face challenges due to the lack of theoretical background and evidence-based business models promoting their use (Renz \& Hilbig, 2020). These limitations are linked to challenges that institutions face related to technological infrastructure, hardware, and software (Ponomarenko et al., 2019), as teachers require information to implement organisational and strategic developments with innovative pedagogies. 
Finally, from the learner perspective, the digital divide remains in terms of access to technology (De Wit et al., 2015). At the international and internal levels, the digital divide is a cause for concern in Europe in those countries considered to be digital leaders (Cruz-Jesus et al., 2016). Consequently, equal emphasis on digital skills and infrastructure development of digital platforms is required to help institutions meet their students' needs in relation to the digital divide (Chetty et al., 2018).

\section{Purpose of the Present Study}

Based on a prior study by Guàrdia and Maina (2018), our research explores technology use as a driver of innovative change in higher education and its associated trends, challenges, and pedagogical practices facing the new, uncertain pandemic scenario. We aim to identify broad themes in innovative practices and the institutional initiatives that exemplify sound educational practices. The results are organised into a structured framework that will offer insight to universities that want to modernize and benefit from technologies and that will aid policy makers and university directors in their decisionmaking strategies in relation to innovation in higher education. Finally, we hope to spark debate about the future of universities given that in these unprecedented times, the future is now.

\section{Research Design}

Our study unfolds in three consequent phases as per the thematic synthesis guidelines of Thomas and Harden (2008). Adopting this approach facilitates the coding of findings, as well as the selection of descriptive themes, which in turn supports the development of the presented framework by providing a clearer understanding of the identified themes and initiatives (Vryonides et al., 2014). An overview of the research phases of this article is provided in Figure 1. 


\section{Figure 1}

Overview of Research Stages

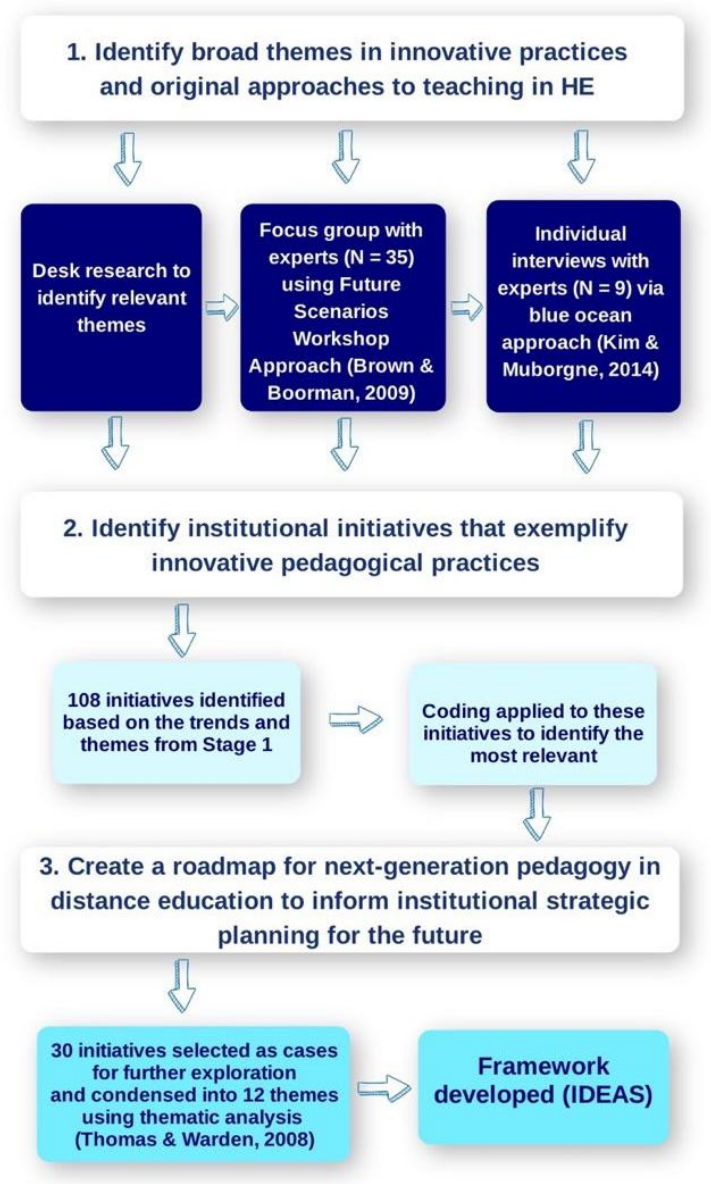

Stage one involved desk research of the academic and grey literature related to broad themes in innovative practices and original approaches (see Table 1) to teaching in higher education from 2015 to 2020. Prior to the search, the key themes were identified based on relevant academic reports, documented practices, and the researchers' professional expertise in innovative practices using information and communications technology. Projects financed in competitive calls were used as a reference to indicate the trends prioritized in education. We began our search using the term innovative practices, chosen for its specificity to the objective of this research. Using the Boolean operator AND, the innovative practices search term was linked to search terms related to higher education and technology, including higher education OR technology OR original approaches OR educational practices. Backward snowballing was used to expand the number of sources found within the reference lists of the reviewed literature to identify additional papers (Wohlin, 2014). The citation chaining option in Google Scholar was then used to further the literature search as it offers suitable coverage for systematic reviews (Gehanno et al., 2013) and is scholarly in terms of accuracy, authority, objectivity, currency, inclusion, and relevance (Howland et al., 2008).

A focus group of leading experts from the field of online education and technology $(n=35)$ was then held using the Future Scenarios workshop approach (Brown \& Boorman, 2009). Working in small groups, participants brainstormed different scenarios for the future of universities, which contributed to the ongoing discussion about future possibilities, opportunities, and challenges in the sector. Finally, 
nine experts chosen for their expertise and research in online education and learning technologies in different geographic areas of the world were interviewed individually based on the results of the focus group, using the blue ocean approach to strategic planning (Kim \& Mauborgne, 2014), which helps organisations discover their own unique selling point to differentiate themselves from similar competitors, thus offering more innovative and sustainable products. The interviews focused on questions regarding which kind of educational model could be devised to help the the experts create their own blue ocean for learning and teaching for institutions, both now and in the future, in terms of pedagogical innovations that do not imitate competitors, which were included in the experts' list of recommendations, highlighting different examples of the suggested innovations.

In stage two, examples of the trends and themes from the first phase were explored. A total of 108 initiatives in online, blended, and lifelong learning from institutions in Europe, the United States, Canada, and Australia were identified. The consulted reports, articles, and various sources discovered in the stage one literature search helped to identify, prioritize, and categorize many of the initiatives chosen. Coding was applied to these initiatives by two external researchers. The first researcher coded all 108 initiatives, and the second reviewed the 30 most relevant initiatives named by the first coder. One point was allocated to any initiative representing an example of either an educational current practice (max. points: 14); a challenge, concern, or area of interest for higher education (max. points: 12); or an innovative or original approach to teaching in higher education (max. points: 34). Initiatives that could not be transferred to an online environment were excluded; those remaining were captured in a spreadsheet, mapping the initiatives with their descriptions, country or region of impact, the main source of information, notes, and rating in relation to the coding criteria (see Table 2).

In stage three, 30 of the 108 initiatives with the highest ratings in the coding framework were chosen as cases for further in-depth exploration based on their transferability, key aspects, probability of bringing about significant change in higher education, and present innovations and trends identified in the literature. The main objective was to propose significant attributes to consider for next-generation pedagogy to inform institutional strategic planning for the future (see Tables 3 and 4).

The output of trends and themes were reorganised into a comprehensive set of attributes of nextgeneration pedagogy using the technology, organisation, and pedagogy model's rationale for data reduction (Sangrà et al., 2009), which matches technology, organisation, and pedagogy in e-learning.

\section{Results and Discussion}

A total of 14 trends (Table 1) emerged from stage one and were classified according to the three broad themes of interest: online learning and teaching, blended learning and teaching, and lifelong learning. 


\section{Table 1}

Trends Identified in Desk Research

\begin{tabular}{lll}
\hline \multicolumn{1}{c}{ Online learning and teaching } & \multicolumn{1}{c}{$\begin{array}{c}\text { Blended learning and } \\
\text { teaching }\end{array}$} & \multicolumn{1}{c}{ Lifelong learning } \\
\hline $\begin{array}{l}\text { Collaboration between higher } \\
\text { education institutions }\end{array}$ & $\begin{array}{l}\text { Flipped classrooms } \\
\text { Bring your own device }\end{array}$ & $\begin{array}{l}\text { Vocational and educational } \\
\text { training }\end{array}$ \\
Internationalization & Teacher development & $\begin{array}{l}\text { Collaboration between } \\
\text { universities and employers }\end{array}$ \\
Digital literacy & Flexible and personalised & Informal learning \\
Learning analytics & learning & \\
Massive open online courses & Increased assessment- & \\
Open educational resources & related activities & \\
\hline
\end{tabular}

In the stage two workshop, participants devised a list of 34 innovative approaches to teaching in higher education (Table 2), which influenced the selection of cases for further exploration, informed the final selection of cases, and oriented the content to interview the experts.

Table 2

Innovative Approaches to Teaching in Higher Education

\begin{tabular}{|c|c|}
\hline Number & Innovative approach \\
\hline 1. & Adaptive learning technologies \\
\hline 2. & Artificial intelligence \\
\hline 3. & Augmented reality \\
\hline 4. & Authenticity \\
\hline 5. & Event-based learning \\
\hline 6. & Community of inquiry \\
\hline 7. & Community of interest \\
\hline 8. & Community of practice \\
\hline 9. & Competency-oriented education \\
\hline 10. & Connectivism \\
\hline 11. & Data portability \\
\hline 12. & Disaggregated services \\
\hline 13. & Digital badges \\
\hline 14. & E-portfolios \\
\hline 15 . & Gamification \\
\hline 16. & Inquiry-based learning \\
\hline 17. & Internet of things \\
\hline 18. & Learning and performance support systems \\
\hline 19. & Meta-cognitive learning approach \\
\hline 20. & Modularity \\
\hline 21. & Personal learning environment \\
\hline 22. & Problem-based learning \\
\hline 23. & Project- and problem-based learning \\
\hline 24. & Recognition of open nonformal learning \\
\hline 25. & Rhizomatic learning \\
\hline
\end{tabular}


26.

27.

28.

29.

30.

31.

32.

33.

34 .
Robotics applied to education

Self-regulated learning

Serious games

Smart learning environment

Social networking for education

Structure opposed to flexibility

Virtual mobility

Virtual reality

Virtual worlds

A thematic analysis-a qualitative method credited as being accessible and theoretically flexible (Braun \& Clarke, 2006)-was applied to the 30 cases selected for further exploration. Twelve overarching themes in innovative practices and original approaches to teaching emerged from the selected institutional initiatives (Table 3).

\section{Table 3}

Themes of Innovative Practices and Original Approaches to Teaching in Higher Education

\begin{tabular}{ll}
\hline \multicolumn{1}{c}{ Theme } & \multicolumn{1}{c}{ Key aspect } \\
\hline Active learning & Learner-generated content \\
& Gamification \\
& Problem-based learning \\
Beyond the institutional learning & Remote labs \\
management system & Personalised learning pathways \\
& Educational applications \\
& Software architecture integration \\
Collaboration between higher education & Sharing and joint development of resources and \\
institutions & courses \\
& Benchmarking practices \\
& Increasing offer of staff development opportunities \\
& Enhancing student exchanges \\
Digital literacy (digital competences) & Training programmes for teachers and students to \\
& support digital literacy \\
& Incorporation of learning technologies into \\
& teachers' practices \\
Employability and collaboration between & Digital badges \\
higher education institutions and employers & Placements/internships \\
& Nanodegrees \\
& Use of learning analytics \\
Flexibility and personalisation & Adaptive learning technologies \\
& Stackable degrees \\
Internationalization & Free credits between institutions \\
& Massive open online courses \\
& Innovation projects directed by students and \\
& external stakeholders \\
& Networking between institutions from different \\
& countries \\
& Enrolment of international learners \\
& \\
& \\
& \\
&
\end{tabular}


Learning analytics

Nonformal and open learning

Recognition of prior learning
Student and staff outbound/inbound mobility

Foreign language learning

Globally focused curricula

Transnational delivery of courses

Educational use of Web analytics and other student activity data

Automatic e-mails to students veering offtrack from their studies Increasing communication between institutional representatives and students

Allowing students to understand their progress in comparison to the overall cohort

Live updates for checking students' progress Adaptive learning platforms

Recognizing nontraditional learning

Open educational resources

Massive open online courses

Micro-credentials as recognition for learning achievements

Acknowledgement of learning outside of formal credit award training and educational programmes References from experienced referees List of past achievements Monographs, journal articles, speech notes

Based on the interviews and investigation of innovative approaches and thematic analysis, the data set was reduced to reveal the IDEAS framework, developed as a signpost on the roadmap of next-generation pedagogy, alongside the landmark practices for each one (Table 4). The acronym comprises the five key characteristics of innovative, next-generation pedagogy: Intelligent, Distributed, Engaging, Agile, and Situated.

\section{Table 4}

IDEAS Next-Generation Pedagogy Framework for Transforming Higher Education

\begin{tabular}{cl}
\hline Characteristic & \multicolumn{1}{c}{ Landmark practices } \\
\hline Intelligent (I) & $\begin{array}{l}\text { Informing educational decisions using learning analytics } \\
\text { Teaching digital competences } \\
\text { Taking learning and teaching beyond the institutional learning platform } \\
\text { Creative use of emerging technologies }\end{array}$ \\
\hline Distributed (D) & $\begin{array}{l}\text { Making the most of partnerships with other institutions, employers, or } \\
\text { professional bodies } \\
\text { Disaggregating teaching, content provision, assessment, academic support, and } \\
\text { other services } \\
\text { Involving a wider community of interest in research and teaching activities }\end{array}$ \\
\hline
\end{tabular}




\section{Engaging (E) Designing for active learning: encouraging problem solving and knowledge construction by learners \\ Reducing the focus on content and increasing the focus on learning}

Agile (A) Facilitating personalisation and flexibility of learning pathways

Expanding options for recognition of prior learning

Widening participation in higher education

Fostering internationalization and student mobility

Situated (S) Contextualising learning and assessment activities in the real world

Expanding work-related learning opportunities

Focusing on society's big issues

Intelligent pedagogy involves the use of technology such as learning analytics to enhance the learning experience. Learning analytics helps to identify students who are offtrack with their studies, update them with live progress reports, identify popular learning materials and methods to adapt coursework according to individual learners needs, and replace the learning management system with student data management, human resources management, and/or financial management. Teaching DC is another landmark practice to consider as a student learning outcome, as well as providing DC training and development for staff, and establishing a DC institutional culture. Also, taking learning and teaching beyond the institutional learning platform is vital and can be achieved by encouraging students to be curators/creators of online platforms relevant to the course content, creation, and/or participation in virtual/collaborative project work platforms for students and staff-so they can work with professionals and community members outside of the institution-and by ensuring that software architecture incorporates a range of educational applications (tools, systems, content). These practices encourage active learning by increasing student autonomy and the creative use of emerging technologies such as remote labs or augmented and virtual reality that enhance learners' educational experiences. Additionally, the use of mobile device apps that support learning via student input and collaboration could be implemented.

Distributed pedagogy is related to the shared ownership of aspects of the learner's journey by various stakeholders in the process. It includes collaborative alliances between institutions and a deliberate disaggregation of services to let learners choose their learning experience from a competitive marketplace, demonstrating that a university education no longer depends on institutions to provide learning materials, teaching, and accreditation, as they have more freedom in the services they provide. Thus, increasing focus on strategic partnerships through collaboration, building curricula and credentials with employers/employer bodies, tailoring programmes to enhance students' employability and support innovation in the industry, and partnering with agencies that can provide specific services for more flexibility such as 24-hour academic support for students is needed. Further elements of this practice include open access to courses and course materials alongside assessment and formal credits for successful demonstration of learning outcomes, institutional collaboration to recognize credits obtained via open/nonformal learning, offers of challenge exams and recognition of prior learning, and learners' empowerment to receive formal credit for learning from a variety of formal and informal sources. Finally, involving a wider community of interest in research and teaching activities such as projects that students can work on with professionals and interested members of the public to address problems of wider interest to society is recommended. 
Engaging pedagogy encompasses students' desires to be engaged by what they are learning. Examples of effective practices for this characteristic include strategic design for active learning-which implies learners having a more active role in content generation-active use of technology for learning, learnerbuilt portfolios, appropriate use of gamification, and learners' encouragement to proactively seek and use teacher, peer, and wider academic community feedback. Both a reduced focus on content and an increased focus on learning are also needed. Reducing the course content and replacing it with learnerfocused content-that is, learners find and evaluate information and apply it to real-life contexts and approaches to learning that include problem solving and project work in teams-are recommended. It is crucial to support teaching staff in creating engaging pedagogy by encouraging them to find, select, reflect on, and participate in learning activities that match their levels of expertise; offering teaching enhancement programmes that fit easily into their workload; and ensuring recognition for continuing professional development (e.g., digital badges/micro-credentials).

Agile pedagogy addresses the need for flexibility and responsiveness to learners' needs. Facilitating personalisation and flexibility can be achieved by modularizing degree programmes as stand-alone blocks to be studied at home or at partner institutions, providing different entry points to degree programmes, eliminating preset deadlines and maintaining fixed schedules for assessment of learning, providing self-assessment tools so students can decide if a flexible programme suits them, proposing optimal course plans (learning pathway) with grade requirements and milestones, offering a variety of personalised assistance services such as online tutoring to support students, and tailoring communications and rapid responses to individual students' and teachers' needs, as well as tailoring access to learning resources, activities, and support to users.

Expanding the options for recognition of prior learning involves issuing micro-credentials-for example, nanodegrees, digital badges, or skill certificates endorsed by employers based on successful completion of assessment; showcasing digital badges/credits on students' online profiles; integrating eportfolios into students' personal learning environments; and awarding academic credits for evidence of prior learning. Moreover, the following actions are also recommended: widening participation by recruiting lifelong learners as opposed to traditional undergraduates; offering students money-saving and time-saving options or a subscription-based fee whereby students pay less based on the time taken to complete the programme or free online courses; offering resources as transition points/credits towards formal degree programmes; and encouraging sponsorship to support free access to personalised support, academic credits, and certificates of achievement to online employment-focused MOOCs.

Another aspect of agile pedagogy refers to promoting internationalization and student mobility through partnerships with other universities, inviting students to experience different pedagogies and perspectives by taking a course or a number of free credits to use on MOOCs or distance courses offered by other institutions.

Situated pedagogy refers to the real-world relevance of the curriculum and the contextualisation of the learning process in terms of learners' personal/professional goals. To contextualise learning activities, educators should ensure that teaching and assessment reflect authentic contexts, giving learners the opportunity to apply the knowledge they have learnt and partner with companies, community organisations, government institutions, and nongovernmental organisations to identify key job-related competencies and integrate career development opportunities into the curriculum. They can then create an online platform to facilitate the coordination, development, and documentation of real-world 
projects. Further practices include expanding work-related learning opportunities via virtual mobility and placements; providing internships and research projects for industry clients; integration of assessments that simulate on-the-job work into programmes, emphasising feedback over grades; incentivising student participation in business projects by paying for successful solutions; offering online access to job vacancies, employer lectures, international opportunities, networking events, career profiles, and CV building resources; enabling students to demonstrate their knowledge and capabilities to prospective employers via a video platform; encouraging alumni to share work-related experiences with current students; and providing mentoring and/or internships and embedding innovation and entrepreneurship knowledge and skills in the course content.

Finally, big issues in society should be addressed. Practices aimed at achieving this goal include the following: student-led entrepreneurial activities or research projects using input from the public/community partners on custom-built platforms; collaborations with nonprofit organisations that widen participation in higher education-for example, programmes targeted at the refugee community; and engagement in local and regional initiatives for environmental protection and sustainability.

\section{Conclusions}

Higher education is being pushed to undergo rapid change and transformation. All higher education institutions, educational leaders, and administrators are expected to remain up to date with technological trends and societal demands, while continuing to provide high-quality education. The aim of this study was to detect the key themes, concerns, and examples of pedagogical innovative practices that drive transformation in higher education. A review of the extant literature alongside experts' opinions and thematic analysis revealed the most crucial areas for discussion in terms of technology, organisation, and pedagogy, as captured by the IDEAS framework. Focusing on the core framed characteristics here identified could encourage innovation in curriculum design and permit institutions to demonstrate their strengths and unique pedagogical approaches that differentiate them in the context of globalized education.

Our research focused on pedagogical innovation supported by technology as a catalyst for nextgeneration pedagogy supported by studies that highlight the key role of technology in both development and change in higher education (Goh et al., 2020; Haywood et al., 2015; Westine et al., 2019). A prime example is learning analytics: research shows that they influence student outcomes, and in organizational terms are useful for student assessment (Marshall, 2018), and can improve learning practices in the learning process (Viberg et al., 2018).

Another relevant outcome from our research is the emphasis on the need to ensure DC for both staff and students. It is essential that staff are digitally competent in order not only to implement and adopt innovative pedagogical practices but also to promote pro-change attitudes. Research has suggested that negative attitudes to change in teaching methods can limit advances in their implementation (Bates, 2019; Englund et al., 2017; Watty et al., 2016). Therefore, the need to include DC as a core objective in institutional and organisational planning is emphasised as it can complement the implementation of the necessary pedagogical and technological changes detected in our study. For students, DC is linked to the increased focus on active learning and students as autonomous actors in choosing and defining their learning trajectory. A major factor behind this is the student who no longer depends solely on 
traditional learning resources to continue their personal and professional development (Henderikx \& Jansen, 2018; Wick et al., 2015).

Furthermore, our study creates a space for debate and reflection with regard to the COVID-19 pandemic. The IDEAS framework proposes a set of key strategic points regarding challenges and trends in the field and highlights the most urgent aspects that need to be addressed. The pandemic has demonstrated that many higher education institutions remain strategically unprepared to provide quality education in times of crisis, as seen in the difficulties reported globally when educators were forced to move their classes online (Gasevic, 2020). IDEAS provides a response that can help in a priori strategic and organisational planning as a robust method to prepare for the near future of higher education.

In summary, this article provides an overview of the current changes, trends, and challenges at the centre of higher education's transformation, highlighting pedagogical innovation supported by technology as a core aspect. The IDEAS framework is intended to be indicative rather than comprehensive and descriptive rather than prescriptive. It is proposed as a guide to identify crucial issues and to support decision making, organisational planning, and structural design, thus developing strategies for institutions to remain at the cutting edge of transformational higher education while addressing challenges and concerns. It can be used to spark reflective thinking, brainstorming, debate, and imaginative planning for future policies at the institutional and cross-institutional levels. Finally, it can be applied to further research in the various associated themes being investigated by providing focal points to develop and explore hypotheses.

\section{Acknowledgements}

This article is based on an internal report for the University of Catalonia, referenced here:

Witthaus, G., Padilla Rodriguez, B. C., Guàrdia, L., \& Girona Campillo, C. (2016). Next generation pedagogy: IDEAS for online and blended higher education. Final report of the FUTURA (Future of University Teaching: Update and a Roadmap for Advancement) Project. Barcelona: Universitat Oberta de Catalunya. Available at: http://openaccess.uoc.edu/webapps/o2/handle/10609/51441 


\section{References}

Amhag, L., Hellström, L., \& Stigmar, M. (2019). Teacher educators' use of digital tools and needs for digital competence in higher education. Journal of Digital Learning in Teacher Education, 35(4), 203-220. https://doi.org/10.1080/21532974.2019.1646169

Baldwin, S. J., \& Ching, Y.-H. (2019). Online course design: A review of the Canvas Course Evaluation Checklist. The International Review of Research in Open and Distributed Learning, 2O(3), 269-282. https://doi.org/10.19173/irrodl.v20i3.4283

Bates, T. (2019). Teaching in a digital age: Guidelines for designing and learning (2nd ed.). Tony Bates Associates Limited. https://open.umn.edu/opentextbooks/textbooks/teaching-in-adigital-age-guidelines-for-designing-teaching-and-learning-for-a-digital-age

Bates, T. (2020, March 9). Advice to those about to teach online because of the corona-virus. Tony Bates. Retrieved February 26, 2021, from https://www.tonybates.ca/2020/03/o9/advice-tothose-about-to-teach-online-because-of-the-corona-virus/

Bennett, S., Lockyer, L., \& Agostinho, S. (2018). Towards sustainable technology-enhanced innovation in higher education: Advancing learning design by understanding and supporting teacher design practice. British Journal of Educational Technology, 49(6), 1014-1026. https://doi.org/10.1111/bjet.12683

Bozkurt, A., Jung, I., Xiao, J., Vladimirschi, V., Schuwer, R., Egorov, G., Lambert, S., Al-Freih, M., Pete, J., Olcott, D., Jr., Rodes, V., Aranciaga, I., Bali, M., Alvarez, A. J., Roberts, J., Pazurek, A., Raffaghelli, J. E., Panagiotou, N., de Coëtlogon, P. ... Paskevicius, M. (2020). A global outlook to the interruption of education due to COVID-19 pandemic: Navigating in a time of uncertainty and crisis. Asian Journal of Distance Education, 15(1), 1-126. https://www.asianjde.org/ojs/index.php/AsianJDE/article/view/462

Brandenburg, U., de Wit, H., Jones, E., Leask, B., \& Drobner, A. (2020). Internationalization in Higher Education for Society (IHES): Concept, current research and examples of good practice. DAAD Studies. German Academic Exchange Service (DAAD). https://static.daad.de/media/daad de/pdfs nicht barrierefrei/der-daad/analysenstudien/daad s15 studien ihes web.pdf

Braun, V., \& Clarke, V. (2006). Using thematic analysis in psychology. Qualitative Research in Psychology, 3(2), 77-101. https://doi.org/10.1191/1478088706qpo63oa

Brown, M., McCormack, M., Reeves, J., Brook, D. C., Grajek, S., Alexander, B., Bulger, S., Dark, S., Engelbert, N., Gannon, K., Gauthier, A., Gibson, D., Gibson, R., Lundin, B., Veletsianos, G., \& Weber, K. (2020). 2020 EDUCAUSE Horizon Report: Teaching and learning edition. EDUCAUSE. https://library.educause.edu/$\angle$ media/files/library/2020/3/2020 horizon report pdf.pdf?la=en\&hash=08A92C17998E81 13BCB15DCA7BA1F467F303BA80

Brown, N., \& Boorman, S. (2009). Changing landscapes: Future scenarios for variable tuition fees. Universities UK. https://dera.ioe.ac.uk/26285/1/ChangingLandscapes.pdf 
Chetty, K., Qigui, L., Gcora, N., Josie, J., Wenwei, L., \& Fang, C. (2018). Bridging the digital divide: Measuring digital literacy. Economics: The Open-Access, Open-Assessment E-Journal, 12(23), 1-20. https://doi.org/10.5018/economics-ejournal.ja.2018-23

Cruz-Jesus, F., Vicente, M. R., Bacao, F., \& Oliveira, T. (2016). The education-related digital divide: An analysis for the EU-28. Computers in Human Behavior, 56, 72-82. https://doi.org/10.1016/j.chb.2015.11.027

Damewood, A. M. (2016). Current trends in higher education technology: Simulation. TechTrends, 6o(3), 268-271. https://doi.org/10.1007/s11528-016-0048-1

DeVries, I. J. (2019). Open universities and open educational practices: A content analysis of open university websites. The International Review of Research in Open and Distributed Learning, 2O(4), 167-178. https://doi.org/10.19173/irrodl.v20i4.4215

De Wit, H., Hunter, F., Howard, L., \& Egron-Polak, E. (2015). Internationalization of higher education. EU Directorate-General for Internal Policies. https://www.europarl.europa.eu/RegData/etudes/STUD/2015/540370/IPOL STU\%282015 \%29540370 EN.pdf

Englund, C., Olofsson, A. D., \& Price, L. (2017). Teaching with technology in higher education: Understanding conceptual change and development in practice. Higher Education Research \& Development, 36(1), 73-87. https://doi.org/10.1080/07294360.2016.1171300

Farjon, D., Smits, A., \& Voogt, J. (2019). Technology integration of pre-service teachers explained by attitudes and beliefs, competency, access, and experience. Computers \& Education, 130, 8193. https://doi.org/10.1016/j.compedu.2018.11.010

Gasevic, D. (2020, April 26). COVID-19: The steep learning curve for online education. LENS. https://lens.monash.edu/@education/2020/04/26/1380195/covid-19-the-steep-learningcurve-for-online-education

Gehanno, J. F., Rollin, L., \& Darmoni, S. (2013). Is the coverage of Google Scholar enough to be used alone for systematic reviews. BMC Medical Informatics and Decision Making, 13, Article 7. https://doi.org/10.1186/1472-6947-13-7

Gillett-Swan, J. (2017). The challenges of online learning: Supporting and engaging the isolated learner. Journal of Learning Design, 1O(1), 20-30. https://doi.org/10.5204/jld.v9i3.293

Goh, C. F., Hii, P. K., Tan, O. K., \& Rasli, A. (2020). Why do university teachers use e-learning systems? The International Review of Research in Open and Distributed Learning, 21(2), 136-155. https://doi.org/10.19173/irrodl.v21i2.3720

Guàrdia, L. \& Maina, M. (2018). FUTURA - Next generation pedagogy. IDEAS for Online and Blended Higher Education. In G. Ubachs \& L. Konings (Eds.), The envisioning report for empowering universities (pp. 28-30). EADTU.

http://empower.eadtu.eu/images/report/The_Envisioning_Report_for_Empowering_Unive rsities 2nd edition 2018.pdf 
Haywood, J., Connelly, L., Henderikx, P., Weller, M., \& Williams, K. (2015). The changing pedagogical landscape: New ways of teaching and learning and their implications for higher education policy. EADTU. https://eadtu.eu/home/policy-areas/lifelonglearning/publications/404-the-changing-pedagogical-landscape

Henderikx, P., \& Jansen, D. (2018). The changing pedagogical landscape: In search of patterns in policies and practices of new modes of teaching and learning. EADTU. https://eadtu.eu/documents/Publications/LLL/2018 _The Changing Pedagogical_Landscape.pdf

Hodges, C., Moore, S., Lockee, B., Trust, T., \& Bond, A. (2020, March 27). The difference between emergency remote teaching and online learning. EDUCAUSE Review. https://er.educause.edu/articles/2020/3/the-difference-between-emergency-remoteteaching-and-online-learning

Howland, J. L., Wright, T. C., Boughan, R. A., \& Roberts, B. C. (2008). How scholarly is Google Scholar? A comparison of Google Scholar to library databases. College and Research Libraries, 7o(3), 227-234. https://doi.org/10.5860/0700227

Jääskelä, P., Häkkinen, P., \& Rasku-Puttonen, H. (2017). Teacher beliefs regarding learning, pedagogy, and the use of technology in higher education. Journal of Research on Technology in Education, 49(3-4), 198-211. https://doi.org/10.1080/15391523.2017.1343691

Johnson, N., Veletsianos, G., \& Seaman, J. (2020). US faculty and administrators' experiences and approaches in the early weeks of the COVID-19 pandemic. Online Learning, 24(2), 6-21. https://doi.org/10.24059/olj.v24i2.2285

Kim, W. C., \& Mauborgne, R. (2014). Blue ocean leadership. Harvard business review, 92(5), 60-72.

Marshall, S. J. (2018). Technology and modern students-The digital natives fallacy. In S. J. Marshall (Ed.), Shaping the university of the future (pp. 197-211). Springer Singapore. https://doi.org/10.1007/978-981-10-7620-6 10

O’Keefe, L., Rafferty, J., Gunder, A., \& Vignare, K. (2020). Delivering high-quality instruction online in response to COVID-19: Faculty playbook. Online Learning Consortium. https://onlinelearningconsortium.org/tools/delivering-high-quality-instruction-in-responseto-covid-19-faculty-playbook/

Phoong, S. Y., Phoong, S. W., Moghavvemi, S., \& Sulaiman, A. (2019). Effect of smart classroom on student achievement at higher education. Journal of Educational Technology Systems, 48(2), 291-304. https://doi.org/10.1177/0047239519870721

Ponomarenko, E., Oganesyan, A., \& Teslenko, V. (2019). New trends in higher education: Massive open online courses as an innovative tool for increasing university performance. International Journal of Economic Policy in Emerging Economies, 12(4), 391-406. https://doi.org/10.1504/IJEPEE.2019.104635 
Posselt, T., Abdelkafi, N., Fischer, L., \& Tangour, C. (2018). Opportunities and challenges of higher education institutions in Europe: An analysis from a business model perspective. Higher Education Quarterly, 73(1), 100-115. https://doi.org/10.1111/hequ.12192

Rapanta, C., Botturi, L., Goodyear, P., Guàrdia, L., \& Koole, M. (2020). Online university teaching during and after the covid-19 crisis: Refocusing teacher presence and learning activity. Postdigital Science and Education, 2(3), 923-945. https://doi.org/10.1007/s42438-02000155-y

Renz, A., \& Hilbig, R. (2020). Prerequisites for artificial intelligence in further education: Identification of drivers, barriers, and business models of educational technology companies. International Journal of Educational Technology in Higher Education, 17(1). https://doi.org/10.1186/s41239-020-00193-3

Romero-Moreno, L. M. (2019). Analysis of the collaboration that is produced in online learning using Python technology. Journal of Information Systems Engineering \& Management, 4(4). https://doi.org/10.29333/jisem/6351

Ruano-Borbalan, J. C. (2019). Innovation in higher education: Actors, policies and pedagogical effects. European Journal of Education, 54(4), 493-498. https://doi.org/10.1111/ejed.12371

Sangrà, A., Guàrdia, L., \& Fernández-Michels, P. (2009). Matching technology, organisation and pedagogy in e-learning: Looking for the appropriate balance leading to sustainability and effectiveness. In M. Stansfield \& T. Connolly (Eds.), Institutional transformation through best practices in virtual campus development (pp. 95-114). https://doi.org/10.4018/978-160566-358-6.choo7

Stefaniak, J., \& Carey, K. (2019). Instilling purpose and value in the implementation of digital badges in higher education. International Journal of Educational Technology in Higher Education, 16(1). https://doi.org/10.1186/s41239-019-0175-9

Sutton, K. K., \& DeSantis, J. (2017). Beyond change blindness: Embracing the technology revolution in higher education. Innovations in Education and Teaching International, 54(3), 223-228. https://doi.org/10.1080/14703297.2016.1174592

Thomas, J., \& Harden, A. (2008). Methods for the thematic synthesis of qualitative research in systematic reviews. BMC Medical Research Methodology, 8(1), 1-10. https://doi.org/10.1186/1471-2288-8-45

Viberg, O., Hatakka, M., Bälter, O., \& Mavroudi, A. (2018). The current landscape of learning analytics in higher education. Computers in Human Behavior, 89, 98-110. https://doi.org/10.1016/j.chb.2018.07.027

Vryonides, S., Papastavrou, E., Charalambous, A., Andreou, P., \& Merkouris, A. (2014). The ethical dimension of nursing care rationing: A thematic synthesis of qualitative studies. Nursing Ethics, 22(8), 881-900. https://doi.org/https://doi.org/10.1177/0969733014551377 
Walder, A. M. (2017). Pedagogical innovation in Canadian higher education: Professors' perspectives on its effects on teaching and learning. Studies in Educational Evaluation, 54, 71-82. https://doi.org/10.1016/j.stueduc.2016.11.001

Watty, K., McKay, J., \& Ngo, L. (2016). Innovators or inhibitors? Accounting faculty resistance to new educational technologies in higher education. Journal of Accounting Education, 36, 1-15. https://doi.org/10.1016/j.jaccedu.2016.03.003

Westine, C. D., Oyarzun, B., Ahlgrim-Delzell, L., Casto, A., Okraski, C., Park, G., Person, J., \& Steele, L. (2019). Familiarity, current use, and interest in universal design for learning among online university instructors. The International Review of Research in Open and Distributed Learning, 2O(5), 20-41. https://doi.org/10.19173/irrodl.v20i5.4258

Wicks, D., \&amp; Lumpe, A. (2015). Electronic Portfolios as Pedagogy: Using bPortfolios for Authentic Assessment of Teacher Knowledge and Skills in the U.S. International Teacher Education: Promising Pedagogies, 22C, 219-232. https://doi.org/10.1108/s1479368720150000022011

Wohlin, C. (2014, May). Guidelines for snowballing in systematic literature studies and a replication in software engineering. Proceedings of the 18th International Conference on Evaluation and Assessment in Software Engineering, Article 38. ACM.

https://doi.org/10.1145/2601248.2601268

\section{Athabasca \\ University}

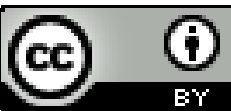

